\title{
The Collection and Conservation of Plant Genetic Resources, Past and Present
}

\author{
Guest editor introduction \\ December 2019 special issue of Culture, Agriculture, Food \& Environment
}

Helen Anne Curry

hac44@cam.ac.uk

In February 2008, the Svalbard Global Seed Vault received its first deposits. The 268,000 inaugural accessions into this "fail-safe facility" included seeds of crops from more than 100 countries. These represented a small part of the "hundreds of millions of seeds" that its creators envisioned would be safeguarded as essential resources for future agricultural production-indeed, for human survival. A press release that year declared that "the vault would enable civilization to re-start agriculture" in the event of global catastrophe. The vault's promoters further projected that it "may become one of the most important and recognizable structures on earth" (Svalbard Global Seed Vault 2008a, 2008b).

In the intervening decade, the Svalbard Global Seed Vault has achieved an iconic status in the popular press and academic circles. Its spartan, snowbound façade inspires art and film, and illustrates countless magazine spreads about the endangerment of crop diversity and the salvation offered by the "doomsday vault." Meanwhile scholars have plumbed the vault's existence for insights into contemporary conservation (e.g., Alpsancar 2016, Wickson 2016, Harrison 2017).

Although the Svalbard vault receives the lion's share of attention, it is only one of about 1750 seed banks worldwide. It represents the most recent iteration of a technoscientific solution first imagined as means to address the loss of crop diversity in the late nineteenth century (Lehmann 1981). The historical development and contemporary workings and of today's sprawling web of institutions and organizations dedicated to the conservation of plant biodiversity remain little known outside the professional world of genetic resources conservation.

In 2017 a small group of scholars convened to discuss the possibilities of extending the history and sociology of seed banking. The papers in this special issue represent some of the research discussed at that workshop. ${ }^{1}$ They engage with older scholarship on seed banking as a global strategy (e.g. Pistorius and Van Wijk 1999) and seed saving as a local practice (Nazarea 2005), while connecting with the recent (and perhaps Svalbard inspired) uptick in interest in these subjects. Historians are providing ever-greater insight into the development of ideas about "genetic resources" and the possibilities of permanently "archiving" these (Fenzi and Bonneuil 2016, Peres 2016, Bonneuil 2019) and the social, political, and economic aspirations that governed the creation of seed banks (Saraiva 2013). Other scholars are exploring the complex views about the pasts and the futures contained in

\footnotetext{
1 "Seeds for Survival: A Workshop on the History and Practice of Seed Banking," held 26-27 June 2017 at the Department of History \& Philosophy of Science, University of Cambridge, with support from the Wellcome Trust.
} 
a seed-and how these in turn influence ideas about their ownership and use (Fullilove 2017, Wincott 2017). Many more researchers are giving attention to seed savers and the roles they play at multiple scales (e.g., Nazarea et al. 2013, Veteto 2014, Pottinger 2017). Wild seed banking has yet to receive the same attention; yet its links to earlier imperial botanical endeavors (Chacko forthcoming) and the complexities of carefully stewarding wildness (Lewis-Jones 2019) indicate the rich possibilities in this field.

The articles in this special issue contribute to our understanding of the historical emergences (Curry, Peres) and present-day functionings (Chacko, Jones) of various modes of conserving plant genetic diversity in seed banks. Exploring both crop plant and wild species conservation at different times and scales, the papers examine how various actors have articulated their role in stewarding plant life for the future as seeds, whether vegetable gardeners, seed bank curators and volunteers, restoration ecologists, or standard-setting agencies. They reveal seed banking and its corollary, seed saving, as a response to uncertainty, one which does not resolve this condition but instead generates new ambiguities and new uncertainties.

Two historical accounts tackle the development of agrobiodiversity conservation into the forms recognized today, reminding us of the contingencies that lie behind the adoption of particular approaches and tools. Sara Peres engages with the concept of "cryopolitics" to explore the historical development of technical standards for seed banks in the 1970s and 80s. The apparently neutral technical decisions meant to address proliferating vulnerabilities and secure "genetic resources" in fact (re)inscribed global power relations. The lens of cryopolitics helps to explain not only critiques of the international seed banking system that arose in the 1980s but also the political geography of seed banking today. My article steps back from this world of professionals to question how and why the common activity of saving and exchanging seed came to be seen by some home-growers as a contribution to global conservation. As I show through the example of a prominent British gardening charity, this transition required intellectual and organizational labor. Although seed saving is, in a sense, "timeless," its contemporary form emerged in the 1970s in juxtaposition to the work of seed banks, and as one among many diverse proposals of how a home gardener could contribute to agrobiodiversity conservation.

Two further papers delve into the practices and problems that animate contemporary gene banking through ethnographic research among scientists and volunteers at the Kew Millennium Seed Bank. Xan Chacko, in a study that offers insights for conservation of both wild and domesticated seed, asks, "What does it mean to bank a seed?" Her observations reveal not just the labor of transforming a collected seed into a gene bank accession but also the care and creativity that infuse this laboratory process. Banked seeds are made, not born, and the processes of their making shape their-and ourfutures. Kay Evelina Lewis-Jones visits both the laboratory and the field, following those professionals who imbue the collection and storage of wild seeds with their aspirations for particular futures. Her interviews highlight the challenges and contradictions of saving "wild" plants through seed-bank-based stewardship because of the intensive intervention required for seed banking and ecological restoration and the ways that institutional and political contexts shape these activities. 
These articles examine a small portion of the activities that inform contemporary conservation of plant biodiversity in seed and gene banks, a task which consumes significant resources and, in part because of the iconic Doomsday vault, garners increasing public attention. There is much to be gained from taking a closer look-as historians, ethnographers, sociologists, anthropologists and others-at how and why we bank seeds in the ways we do.

\section{Bibliography}

Alpsancar, Suzana. 2016. "Plants as Digital Things: The Global Circulation of Future Breeding Options and their Storage in Gene Banks." Technoscienza 7 (1): 45-66.

Bonneuil, Christophe. 2019. "Seeing Nature as a 'Universal Store of Genes': How Biological Diversity Became 'Genetic Resources', 1890-1940." Studies in History and Philosophy of Biological and Biomedical Sciences 75: 1-14.

Chacko, Xan. Forthcoming. "Digging up Colonial Roots: The Less-known Origins of the Millennium Seed Bank Partnership." Catalyst.

Fenzi, Marianna, and Christophe Bonneuil. 2016. "From 'Genetic Resources' to 'Ecosystem Services': A Century of Science and Global Policies for Crop Diversity Conservation." CAFE 38 (2): 72-83.

Harrison, Rodney. 2017. "Freezing Seeds and Making Futures: Endangerment, Hope, Seucrity, and Time in Agrobiodiversity Conservation Practices." CAFE 39 (2): 80-89.

Lehmann, Christian O. 1981. "Collecting European Land-races and Development of European Gene Banks-Historical Remarks." Die Kulturpflanze 29 (1): 29-40.

Lewis-Jones. Kay. "Holding the Wild in the Seed: Place, Escape and Liminality at the Millennium Seed Bank Partnership." Anthropology Today 35 (2): 3-7.

Nazarea, Virginia D. 2005. Heirloom Seeds and Their Keepers: Marginality and Memory in the Conservation of Biological Diversity. Tucson: University of Arizona Press.

Nazarea, Virginia D., Robert E. Rhoades, and Jenna E. Andrews-Swann, eds. 2013. Seeds of Resistance, Seeds of Hope: Place and Agency in the Conservation of Biodiversity. Tucson: University of Arizona Press.

Peres, Sara. 2016. "Saving the Gene Pool for the Future: Seed Banks as Archives." Studies in History and Philosophy of Science-Part C 55: 96-104.

Pistorius, Robin, and Jeroen Van Wijk. 1999. The Exploitation of Plant Genetic Information: Political Strategies in Crop Development. Wallingford: CABI.

Pottinger, Laura. 2017. "Planting the Seeds of a Quiet Activism." Area 49 (2): 215-22. 
Saraiva, Tiago. 2013. "Breeding Europe: Crop Diversity, Gene Banks, and Commoners." In Cosmopolitan Commons: Sharing Resources and Risks Across Borders, edited by N. Disco and E. Kranakis, 185-212. Cambridge: MIT Press.

Svalbard Global Seed Vault. 2008a. "Arctic 'Doomsday' Seed Vault Opens Doors For 100 Million Seeds." ScienceDaily. www.sciencedaily.com/releases/2008/02/080226092753.htm

Svalbard Global Seed Vault. 2008b. "'Doomsday Seed Vault' to Open in Arctic Circle on February $26^{\text {th }}$." Media Advisory, 26 February. www.croptrust.org/press-release/arctic-seedvault-opens-doors-100-million-seeds

Veteto, James R. 2014. "Seeds of Persistence: Agrobiodiversity in the American Mountain South." CAFE 36 (1): 17-27.

Wickson, Fern. 2016 "Do We Care About Synbiodiversity? Questions Arising from an Investigation into Whether There are GM Crops in the Svalbard Global Seed Vault." Journal of Agricultural and Environmental Ethics 29 (5): 787-811.

Wincott, Abigail. 2017. "Treasure in the Vault: The Guardianship of 'Heritage' Seeds, Fruit and Vegetables." International Journal of Cultural Studies 21 (6): 627-642. 